and deformities. I think we might pay close attention to the use of these terms in our deliberations; for example, in cervical lesions one can see spasticity and certainly contractures without any spasticity, and you can see contractures even with lower neurone lesions.

\title{
FOLLOW-UP OF A SERIES OF PHENOL SPINAL BLOCKS
}

By Dr. E. Apolinario, M.D., Dr. J. C. Dominelli, M.D., Dr. M. Fernandez, M.D. and Dr. F. Sotelano, M.D.

National Rehabilitation Centre, Buenos Aires, Argentina

THE interference of spasticity upon urinary tract function and activities of daily living has led us to use intrathecal phenol blocks for therapeutic purposes in a group of spinal patients.

Our present report is a follow up of those I5 patients who were reported at the 1965 meeting of the International Medical Society of Paraplegia (Table). Results were evaluated according to neurological, urological findings, performance of A.D.L. and bioelectrical findings.

(a) Neurological Findings. The myotatic reflexes belonging to the area of injected nerve roots were absent $\mathrm{I} \frac{1}{2}$ years after the block.

The polysynaptic reflexes were completely abolished in most cases, only a few showed a weak reflex response on plantar stimulation and a persisting Babinsky sign. Effects upon muscle power and sensation could not be tested because most of the patients had complete lesions.

(b) Urological Findings. In patients who were catheter free prior to the block there was no loss of bladder control. Frequency of micturition was unchanged. Those who had an interrupted urine stream because of spasms gained a free micturition after blocking. In only one case the residual urine was increased and an indwelling catheter had to be inserted. In this patient bladder sensation was also lost.

(c) Performance of Activities of Daily Living. This improved a great deal. Patients had no longer any difficulty in dressing the lower limbs and transferring in and out of bed, wheelchair and car was easily achieved.

(d) Bioelectrical Findings. Electromyography of the muscles corresponding to blocked areas showed complete absence of electrical activity, either at rest or on stimulation. The non-affected muscles showed a lesser degree of activity than that obtained in the previous records.

\section{RESULTS}

Abolishment of spasticity in order to obtain a better functional ability was achieved and remained permanent.

As was to be expected, spasticity in non-blocked areas had to be treated with other procedures: tenotomies in five cases, peripheral nerve block in one case, and phenol spinal block of the opposite side in another one. 
TABle

\begin{tabular}{|c|c|c|c|c|c|c|c|c|c|c|c|c|}
\hline Case & Aetiology & Level & $\begin{array}{l}\text { Dur } \\
\text { Para }\end{array}$ & $\begin{array}{l}\text { ation } \\
\text { of } \\
\text { alysis }\end{array}$ & $\begin{array}{l}\text { Type of } \\
\text { Spasticity }\end{array}$ & $\begin{array}{l}\text { Type of } \\
\text { Bladder }\end{array}$ & Side & $\begin{array}{l}\text { Phenol } \\
\text { Concentr. }\end{array}$ & Results & $\begin{array}{c}\text { Bladder } \\
\text { after } \\
\text { Block }\end{array}$ & $\begin{array}{l}\text { Time } \\
\text { after } \\
\text { Block }\end{array}$ & Remarks \\
\hline & & & yr. & $\mathrm{m}$ & & & & per cent. & & & yr. m. & \\
\hline I & traum. & C6 & I & 2 & flex. & $\begin{array}{l}\text { normal } \\
\text { reflex }\end{array}$ & unilat. & 20 & good & N. reflex & I 5 & $\begin{array}{l}\text { block on } \\
\text { other side }\end{array}$ \\
\hline 2 & traum. & C6 & 3 & 6 & flex. & $\begin{array}{l}\text { normal } \\
\text { reflex }\end{array}$ & unilat. & 20 & good & & $\cdots$ & died \\
\hline 3 & traum. & $\mathrm{C}_{7}$ & I & 3 & flex. & $\begin{array}{l}\text { normal } \\
\text { reflex }\end{array}$ & unilat. & 20 & good & N. reflex & I 4 & \\
\hline 4 & traum. & $\mathrm{C}_{7}$ & I & 3 & flex. & contract. & unilat. & 20 & good & hypert. & I & \\
\hline 5 & traum. & C6-C8 & 3 & 3 & flex. & $\begin{array}{l}\text { normal } \\
\text { reflex }\end{array}$ & bilat. & $\begin{array}{l}20 \\
15\end{array}$ & good & autonom. & I 5 & \\
\hline 6 & traum. & $\mathrm{D}_{5}$ & & 9 & mixed & hypoton. & bilat. & $\begin{array}{l}10 \\
20\end{array}$ & good & hypoton. & I IO & \\
\hline 7 & traum. & $\mathrm{D}_{5}$ & 6 & IO & flex. & contract. & bilat. & 20 & good & no test & I II & $\begin{array}{l}\text { hip } \\
\text { tenotomy }\end{array}$ \\
\hline 8 & traum. & $\mathrm{D}_{5}$ & I & I & flex. & hypoton. & bilat. & 20 & good & autonom. & I 5 & $\begin{array}{l}\text { tenotomy } \\
\text { nerve } \\
\text { block }\end{array}$ \\
\hline 9 & traum. & DI2 & 3 & 3 & ext. & myogen. & bilat. & 20 & fair & - & -- & died \\
\hline IO & non-traum. & $\mathrm{C}_{8}-\mathrm{L}_{3}$ & I & 7 & flex. & myogen. & bilat. & IO & fair & myogen. & 25 & \\
\hline II & non-traum. & $\mathrm{D}_{5}$ & 13 & & ext. & myogen. & unilat. & 20 & good & myogen. & I 17 & \\
\hline $\mathrm{I} 2$ & non-traum. & $\mathrm{D} 6$ & 3 & IO & ext. & hypert. & unilat. & 15 & good & $\begin{array}{l}\text { normal } \\
\text { reflex }\end{array}$ & I I I & \\
\hline I3 & non-traum. & $\mathrm{D} 8-\mathrm{S}_{3}$ & I & & mixed & hypert. & bilat. & 20 & good & hypert. & I IO & \\
\hline I4 & non-traum. & Dio & 3 & 2 & flex. & $\begin{array}{l}\text { normal } \\
\text { reflex }\end{array}$ & unilat. & 20 & bad & hypot. & I 5 & \\
\hline I 5 & non-traum. & DII & 4 & 6 & ext. & contract. & bilat. & 20 & good & - & - & died \\
\hline
\end{tabular}


As far as urinary function is concerned, myogenic bladders and those that were not tested because of severe complications did not change their previous state. In one patient a persisting hypertonic bladder compelled us to block the sacral nerves, which resulted in an autonomous bladder. Out of a group of eight reflex bladders, seven of them continued to be automatic, though one of them was hypotonic and one became autonomic. One hypotonic reflex bladder remained unchanged.

The final result of phenol block after periods from I year 4 months to 2 years 5 months was loss of spasticity selectively to lumbar roots where phenol had been injected. No signs of ascending arachnoiditis developed so far.

This procedure was used mainly in complete cord lesions. A second block was necessary in a few cases.

\title{
MOTOR POINT INJECTIONS WITH DILUTED ALCOHOL AND INTRATHECAL INJECTIONS THROUGH THE VERTEBRAL FORA- MINA WITH ABSOLUTE ALCOHOL
}

\author{
By M. Lacombe, B. Audic, and M. Maury \\ Centre de Reéducation Motrice de Fontainebleau, France
}

IN our experience with paraplegics, in about 20 per cent. of the patients spasticity is a complication in rehabilitation, a hindrance to independence and considerably increases the hazard of bed sores and fractures.

Early accurate nursing decreases the incidence of incapacitating spasticity. If therapy becomes necessary, the choice may be difficult. We must take great care not to aggravate the patient's misery.

In this respect, we think that two technical aspects are valuable in the minor therapies:

(a) intramuscular injections of diluted alcohol;

(b) sub-arachnoid injections of absolute alcohol through the vertebral foramina.

Intramuscular Injections of Diluted Alcohol. We have been experimenting this technique, following Professor Tardieu, who obtained interesting results, first with decerebrated cats, secondly with children suffering from cerebral palsy. We firstly inject $2 \mathrm{ml}$. of I per cent. xylocaine at the motor points. If we have a response within 6 min. (decreasing hypertonia or clonus) we inject through the same needle $2 \mathrm{ml}$. of alcohol. If there is no result with the xylocaine we move the needle for another trial. We exceptionally had no response after two trials. We use mostly 45 per cent. alcohol. If we get an inadequate result or if there is a return of spasticity, we make another attempt with 60 per cent. alcohol. We often had to do up to four injections in the same muscle, but always with intervals of more than I 5 days, sometimes after one year (for example when required by a check-up patient).

Animal experiments showed that xylocaine and alcohol suppress the stretch reflex by an elective paralysis of the motor fibres, easier to accomplish because they are thinner. 